\title{
AiMT
}

Advances in Military Technology

Vol. 15, No. 2, 2020, pp. 221-230

ISSN 1802-2308, eISSN 2533-4123

DOI 10.3849/aimt.01384

\section{The Effect of Biodiesel on Combustion, Performance and Emission Characteristics of DI Diesel Engine}

\author{
H. Hai Nguyen ${ }^{1}$ and Š. Čorňák ${ }^{2 *}$ \\ ${ }^{1}$ Faculty of Vehicle and Energy Engineering, Le Quy Don Technical University, Hanoi, Vietnam \\ ${ }^{2}$ Faculty of Military Technology, University of Defence in Brno, Czech Republic
}

The manuscript was received on 25 January 2020 and was accepted after revision for publication as research paper on 16 July 2020.

\begin{abstract}
:
Biodiesel fuels play an important role in addressing issues such as food security and environmental pollution. Diesel oil fuel and biodiesel-diesel blends (including B5S, B10S, and B100S which are produced from the rubber seed oil by supercritical methods) are going to be examined in this study. Engine performance, emissions and combustion characteristics of diesel engine were studied. The results of this experimental research show that the oxygen content of biodiesel helps to improve combustion, reduce ignition delay and decrease a significant amount of smoke density emitted from the engine; however, improved combustion has resulted in a slight increase in the amount of $N O_{x}$. The results from this study have made contribution to the development and use of biodiesel fuel.
\end{abstract}

\section{Keywords:}

biodiesel, combustion process, rubber seed oil, supercritical method

\section{Introduction}

Biodiesel fuel is not only considered a renewable energy resource, but also a tool to solve many other problems of people and society. Dependence on fossil energy resources has caused problems such as exhaustion of energy sources and environmental pollution. According to the forecast of the world, energy council fossil fuel resources will run out in the next few decades. This has encouraged the researchers to try and find alternative fuel sources for fossil fuels, which would meet the emission standards. To solve this problem, many countries around the world have created different strategies how to develop renewable energy sources [1].

Typically, rubber seed oil (RSO), which is non-edible, is considered a prospective feedstock for biodiesel production [2-4]. By the year 2020, there may be about

\footnotetext{
* Corresponding author: Department of Combat and Special Vehicles, University of Defence in Brno, Kounicova 156/65, CZ-662 10 Brno, Czech Republic. Phone: +420 973443 438, E-mail: stefan.cornak@unob.cz.ORCID 0000-0002-6664-0364
} 
one million hectares of rubber trees planted in Vietnam and the estimated annual availability of rubber seeds can reach to 200 thousand tons, which can yield about 20 thousand tons of rubber seed oil or more, if proper technologies are employed [4]. RSO with high viscosity is pressed from the rubber seed kernels. Alkali-catalyzed reaction is the most popular process in practice for biodiesel production. However, there are some drawbacks in the alkali-catalyzed process, which is not suitable for the oil feedstock containing a high degree of free fatty acids since the alkali and the sideproducts are hard to remove from the final product. Also, the enzymatic methylations do not present consistent conversions. Therefore, for RSO, due to its acid value probably higher than $34 \mathrm{mg} \mathrm{KOH}$ per gram of oil [3] (i.e. high free fatty acids), a complete conversion method is required.

The biodiesel fuel was produced by the supercritical method (SCM) in this experiment. This method does not require catalysts and almost complete conversions can be achieved in a very short time using the same oil [4-9]. Biodiesel production process with SCM has advantages over other processes due to its low use of auxiliary chemicals, and chemicals associated with waste water treatment and feedstock pre-treatment.

The objective of this study is to evaluate the combustion characteristics of a mixture of experimental fuel samples (including 3 fuel samples B5S, B10S and, B100S). They will be compared with conventional diesel fuel by means of measuring the pressure burning in the combustion chamber and calculating the rate of heat release of the direct injection diesel engine to explain the engine performance and emission characteristics of the test fuel. The results from this study can provide important information about the effects of biodiesel fuel from rubber seed oil using supercritical methanol method on the performance of the diesel engines. It also opens up opportunities to use biodiesel fuel from rubber seed oil to reduce dependence on fossil fuels and ensure energy supply in the near future in ASEAN countries.

A critical point, which should be considered is the use of biodiesel in military transport. Military operations often take place in areas where transport systems face many obstacles, causing the situation in which it would be difficult and timeconsuming to transport petroleum to those locations. Moreover, the fossil oil is rapidly becoming scarce. Therefore, using and processing local raw materials (vegetable oil) as an alternative fuel is much more efficient not only in mobile generators but also in combat vehicles.

\section{Experimental Setup and Tested Fuel}

First, experiments are set up to perform the measurement of performance parameters, emissions and combustion characteristics of fuel samples under the same conditions. The choice of different raw material sources and methods of producing biodiesel fuel depends on the production technology as well as the available material sources of each area to meet standards such as ASTM D6751 and EN 14214. The process of transesterification reaction with the supercritical condition of alcohol happens under the condition that the temperature and pressure are higher than the alcohol critical point. In this case, the alcohol chosen for the reaction was methanol, with a critical condition of $240{ }^{\circ} \mathrm{C}$ and $7.85 \mathrm{MPa}$.

\subsection{Experimental Setup}

The experiment was performed on a 1-cylinder engine test bed. Fig. 1 shows a connecting diagram of test devices. The engine is equipped with sensors for lubricating oil 
temperature, coolant temperature, intake air temperature and exhaust gas temperature to ensure stable test conditions and increase the reliability of test results. The engine Kubota RT 125 DI Plus has the parameters as shown in Tab. 1. This engine is equipped with a direct fuel injector, combustion chamber ' $\omega$ ' type. The nozzles have 4 spray holes. The engine is connected to an electric load controller to measure power, torque and speed. The control centre (PUMA) is the device to receive the transmitted signals and send the control signals to the dynamometer (speed and load). Testo 350 portable emission-analyzer and AVL Dismoke 4000 were used to measure exhaust gas emissions of $\mathrm{NO}_{\mathrm{x}}$ and smoke density, respectively. The engine fuel consumption is measured by the volumetric method through a $50 \mathrm{ml}$ burette tube. Pressure in the combustion chamber and intake line is measured by the AVL Quartz Pressure Transducer. An amplifier is connected to the AVL Indiset 620 device to determine the pressure and lift of the injector and the rate of heat release (ROHR).

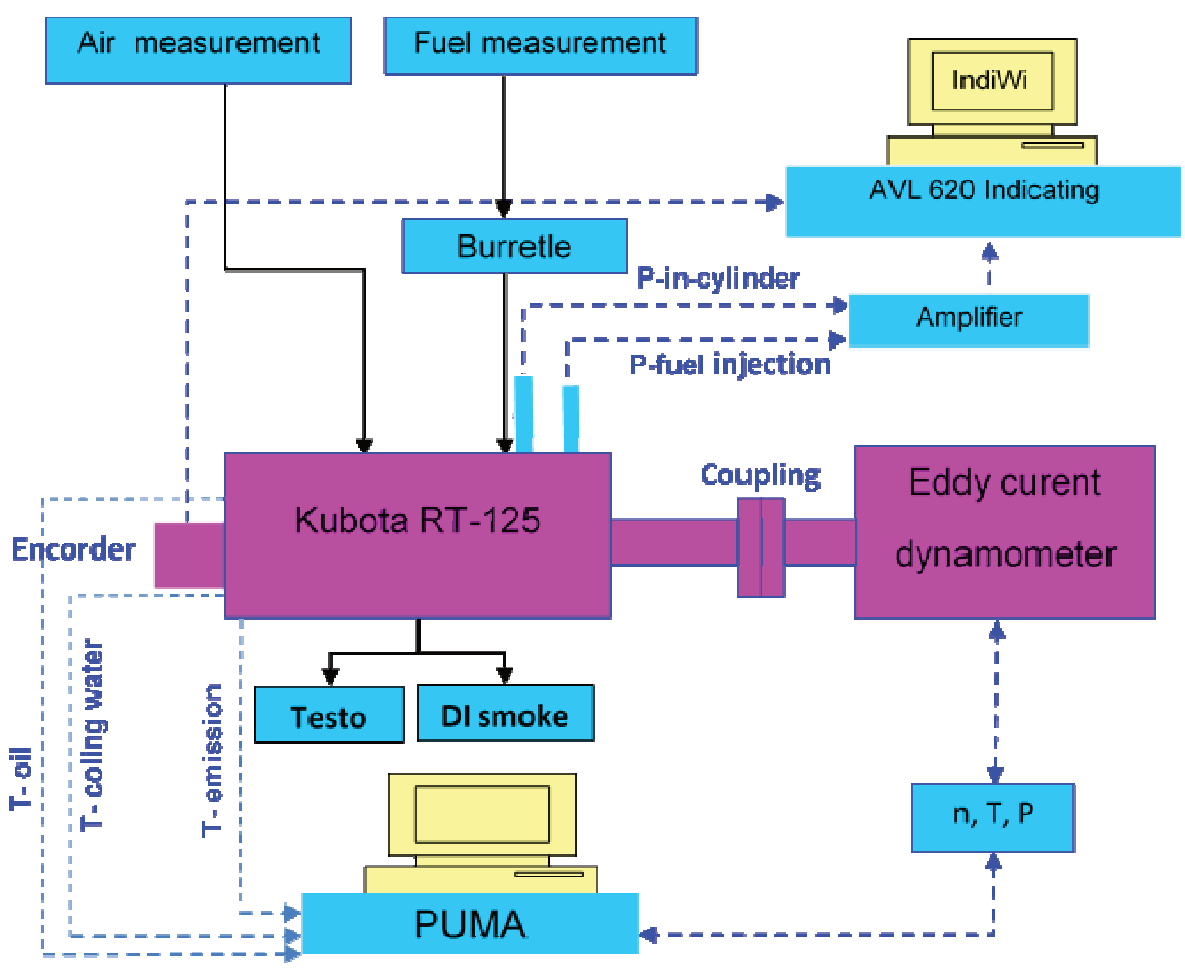

Fig. 1 Schematic arrangement of experimental setup

Tab. 1 Engine specifications

\begin{tabular}{|l|c|}
\hline Engine parameters & Kubota RT125 DI \\
\hline Engine type & 4 strokes, NA \\
\hline Number of cylinder & 1, horizontal type \\
\hline Compression ratio & $18: 1$ \\
\hline Bore $\times$ Stroke $[\mathrm{mm}]$ & $94 \times 96$ \\
\hline Displacement volume $\left[\mathrm{dm}^{3}\right]$ & 0.666 \\
\hline Max. power $[\mathrm{kW}]$ at $2400 \mathrm{rev} / \mathrm{min}$ & 9.3 \\
\hline Injection pressure $[\mathrm{MPa}]$ & 22 \\
\hline
\end{tabular}




\subsection{Experimental Procedures}

Before carrying out the experiment and measuring the test results, the engine was set to run at $800 \mathrm{rev} / \mathrm{min}$ for about $20 \mathrm{~min}$ to warm up the engine until the coolant temperature was reached at $65^{\circ} \mathrm{C} \pm 5{ }^{\circ} \mathrm{C}$. During the test, the laboratory temperature was maintained at $30^{\circ} \mathrm{C} \pm 2{ }^{\circ} \mathrm{C}$. The injection timing was fixed at before top dead centre (BTDC) 14 crank angle $\left({ }^{\circ} \mathrm{CA}\right)$ and the injection pressure was applied at $22 \mathrm{MPa}$. The engine was set to $1600 \mathrm{rev} / \mathrm{min}$ by controlling dynamometer and then changing the torque levels. There are five torque levels including $5.3 \mathrm{~N} \cdot \mathrm{m}, 13.23 \mathrm{~N} \cdot \mathrm{m}, 21.17 \mathrm{~N} \cdot \mathrm{m}$, $29.15 \mathrm{~N} \cdot \mathrm{m}$, and $37.9 \mathrm{~N} \cdot \mathrm{m}$ corresponding to five brake mean effective pressure points (BMEP) including $100 \mathrm{kPa}, 250 \mathrm{kPa}, 400 \mathrm{kPa}, 550 \mathrm{kPa}$ and $700 \mathrm{kPa}$ by the formula [5]:

$$
B M E P=\frac{4 \pi}{V_{\mathrm{d}}}
$$

where $B M E P$ is brake mean effective pressure $[\mathrm{kPa}], \tau$ is the torque produced by the rotating shaft $[\mathrm{N} \cdot \mathrm{m}]$ and $V_{\mathrm{d}}$ is the displacement volume $\left[\mathrm{m}^{3}\right]$.

The combustion pressure, fuel consumption and exhaust measurement were measured when the engine speed was stabilized within $1600 \mathrm{rev} / \mathrm{min} \pm 10 \mathrm{rev} / \mathrm{min}$ and experimental conditions were steady. The combustion pressure was calculated as the average of 100 cycles. The measurement results were taken simultaneously and to ensure accuracy results and they were taken 3 times to get an average.

\subsection{Tested Fuel}

Rubber seeds have been collected from rubber fields in Binh Phuoc Province, Vietnam. After that, rubber seeds were pressed to form rubber seed oil. Rubber seed oil was dark yellow color, without impurities and it was used as feedstock directly for reaction. Oil sample was analyzed by means of gas chromatography-mass spectrometry (GC-MS) in order to determine the composition of fatty acids (as shown in Tab. 2). Methanol was purchased from SigmaAldrich, and its critical point is at the temperature of $239.6{ }^{\circ} \mathrm{C}$ and pressure of $8.09 \mathrm{MPa}$.

Tab. 2 Composition of fatty acids RSO

\begin{tabular}{|l|c|c|}
\hline \multicolumn{1}{|c|}{ Fatty acid } & Formula & Composition [wt.\%] \\
\hline Palmitic Acid (C16:0) & $\mathrm{C}_{16} \mathrm{H}_{32} \mathrm{O}_{2}$ & 10.11 \\
\hline Stearic Acid (C18:0) & $\mathrm{C}_{18} \mathrm{H}_{36} \mathrm{O}_{2}$ & 10.67 \\
\hline Oleic Acid (C18:1) & $\mathrm{C}_{18} \mathrm{H}_{34} \mathrm{O}_{2}$ & 24.4 \\
\hline 11-Octadecenoic Acid, (Z) $(\mathrm{C} 18: 1)$ & $\mathrm{C}_{18} \mathrm{H}_{34} \mathrm{O}_{2}$ & 1.56 \\
\hline Linoleic Acid (C18:2) & $\mathrm{C}_{18} \mathrm{H}_{32} \mathrm{O}_{2}$ & 37.98 \\
\hline Linolenic Acid (C18:3) & $\mathrm{C}_{18} \mathrm{H}_{30} \mathrm{O}_{2}$ & 15.25 \\
\hline
\end{tabular}

Fig. 2 describes the diagram of biodiesel production using the supper critical method. A Parr Instruments 4546 series whose volume is 1.2 litters was employed in this study to produce biodiesel fuel using the SCM. The high-pressure reactor is made 
of SUS316 stainless steel and can be operated up to the maximum temperature of $350{ }^{\circ} \mathrm{C}$ and pressure of $13.79 \mathrm{MPa}$. The biodiesel production was completed with the following reaction conditions: $(i)$ the mole ration between methanol and oil is $42: 1$; (ii) the temperature of the reaction is $280{ }^{\circ} \mathrm{C}$; (iii) the duration of the reaction is $20 \mathrm{~min}$; and (iv) the pressure of the reaction is $8.5 \mathrm{MPa}$. The stirring speed was set at a fixed rate of $300 \mathrm{rev} / \mathrm{min}$. After finishing the reaction, the vessel was removed from the heater and cooling water was supplied in the spiral cooling-coil to quickly cool the reactor, thus quenching the reaction and depressurizing to ambient pressure. Then the mixture was kept at the temperature of $50{ }^{\circ} \mathrm{C}$ for the duration of $20 \mathrm{~min}$ by the vacuum equipment in order to remove and recover the remaining methanol. This mixture was then allowed to settle for about $30 \mathrm{~min}$ to have the two phases separated: the top phase consists of the biodiesel and the lower phase consists of glycerol and other minor components.

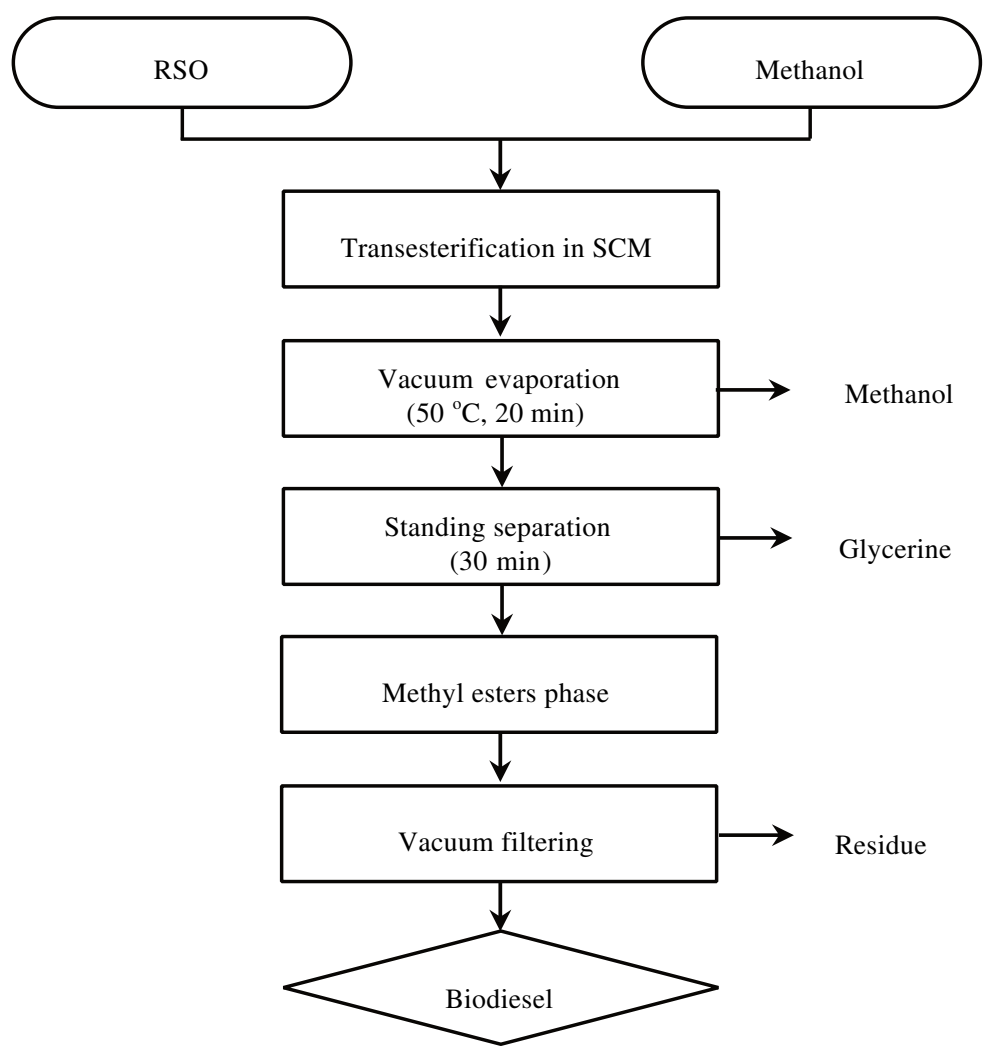

Fig. 2 Diagram of biodiesel production for RSO using SCM

Tab. 3 shows fuel characteristics of four tested kinds of fuel in this study, including: Diesel oil (DO), B5S, B10S, and B100S. The biodiesel-diesel blends are mixed by volume of percentage of $5 \%, 10 \%$ and $100 \%$ biodiesel, respectively, for B5S, B10S and B100S.

Tab. 4 presents the fatty acid methyl ester (FAME) composition of the biodiesel fuel samples measured by gas chromatography-mass spectrometry. The percentage of unsaturated FAME for fuel produced by the supercritical method (SBDF) is $56.26 \%$. 
After the fuel production process the methyl ester content of the unsaturated acid of the fuel sample decreased, while the saturated FAME component increased.

Tab. 3 Fuel characteristics

\begin{tabular}{|c|c|c|c|c|}
\hline Parameters & DO & B5S & B10S & B100S \\
\hline $\begin{array}{c}\text { Density at } 20^{\circ} \mathrm{C} \\
{\left[\mathrm{g} \cdot \mathrm{cm}^{-3}\right]}\end{array}$ & 0.8291 & 0.8292 & 0.8317 & 0.8864 \\
\hline $\begin{array}{c}\text { Kinematic viscosity at } \\
40^{\circ} \mathrm{C}\left[\mathrm{mm}^{2} \cdot \mathrm{s}^{-1}\right]\end{array}$ & 2.9501 & 3.046 & 3.11 & 5.3246 \\
\hline Flash point $\left[{ }^{\circ} \mathrm{C}\right]$ & 68 & 68 & 70 & 184 \\
\hline $\mathrm{HHV}\left[\mathrm{MJ} \cdot \mathrm{kg}^{-1}\right]$ & 56.3 & 55.5 & 55.6 & 45.1 \\
\hline Cetane number & 49 & 49.3 & 49.5 & 51 \\
\hline
\end{tabular}

Tab. 4 Fatty acid methyl ester components of biodiesel fuel

\begin{tabular}{|l|c|c|}
\hline \multicolumn{1}{|c|}{ Fatty acid methyl ester (FAME) } & $\begin{array}{c}\text { Molar mass } \\
{\left[\mathrm{g} \cdot \mathrm{mole}^{-1}\right]}\end{array}$ & $\begin{array}{c}\text { Composition } \\
{[\mathrm{wt} . \%]}\end{array}$ \\
\hline Heptanoic acid, methyl ester C7:0 & 144.21 & 0.37 \\
\hline 6-Heptanoic acid, methyl ester C7:1 & 142.21 & 0.13 \\
\hline Octanoic acid, methyl ester C8:0 & 158.24 & 0.76 \\
\hline Nonanoic acid, methyl ester C9:0 & 172.26 & 0.35 \\
\hline Decanoic acid, methyl ester C10:0 & 186.29 & 1.36 \\
\hline 4-Decenoic acid, methyl ester C10:1 & 184.29 & 0.4 \\
\hline Undecanoic acid, methyl ester C11:0 & 200.32 & 0.13 \\
\hline Dodecanoic acid, methyl ester C12:0 & 214.34 & 3.78 \\
\hline Tetradecanoic acid, methyl ester C14:0 & 242.40 & 1.51 \\
\hline Pentadecanoic acid, methyl ester 15:0 & 256.42 & 0.14 \\
\hline Hexadecanoic acid, methyl ester C16:0 & 270.45 & 18.34 \\
\hline 9-Hexadecenoic acid, methyl ester 16:1 & 268.43 & 0.34 \\
\hline Heptadecanoic acid, methyl ester C17:0 & 284.48 & 0.19 \\
\hline Octadecanoic acid, methyl ester C18:0 & 298.50 & 15.72 \\
\hline Trans-9-Octadecenoic acid, methyl ester C18:1, & 296.49 & 7.08 \\
\hline Cis-9-Octadecenoic acid, methyl ester C18:1, & 296.49 & 32.59 \\
\hline Trans-9, 12-Octadecadienoic acid, methyl ester C18:2 & 294.47 & 1.87 \\
\hline Cis-9, 12-Octadecadienoic acid, methyl ester C18:2 & 294.47 & 13.12 \\
\hline Cis-9, 12, 15-Octadecatrienoic acid, methyl ester C18:3 & 292.46 & 0.6 \\
\hline Eicosanoic acid, methyl ester C20:0 & 326.56 & 1.08 \\
\hline Cis-8,11,14-Eicosatrienoic acid, methyl ester C20:3 & 320.51 & 0.13 \\
\hline
\end{tabular}




\section{Result and Discussion}

The results of experimental research including engine performance, emission and combustion characteristics of fuel samples will be presented in this section.

\subsection{Engine Performance}

Fig. 3 shows the brake specific fuel consumption (BSFC) of fuel samples measured at $1600 \mathrm{rev} / \mathrm{min}$. Fuel consumption tends to decrease from low to high loads for all fuel samples. In particular, the fuel consumption of fuel increases with the rate of mixing biodiesel and fuel consumption of B100S is the highest. The reason for this is the lowest higher heating value (HHV) of this fuel, and also the fact that the density of net biodiesel fuel and biodiesel-diesel blends is higher than that of diesel fuel.

Fig. 4 shows the brake thermal efficiency (BTE) changes at varying load values. Results of the experiment show that efficiency increased with increasing load and reached the peak at $550 \mathrm{kPa}$, then decreased slightly to a load of $700 \mathrm{kPa}$. The thermal efficiency of B100S fuel compared to other test fuel samples is the highest at all loading levels. This can be explained by the occurrence of molecular oxygen in biodiesel, which has helped to improve combustion and increased efficiency compared to diesel fuel. Because the HHV of diesel fuel is higher than blending biodiesel fuels, due to the higher fuel consumption at each load and speed of the engine, the thermal efficiency of biodiesel fuel mixtures is still higher than net diesel fuel.

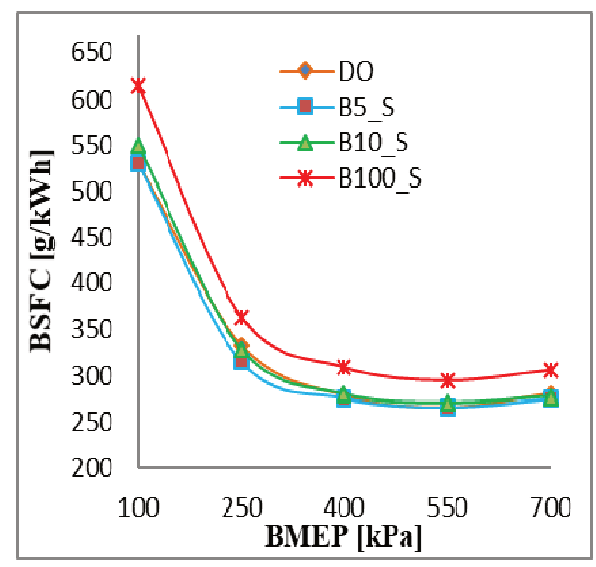

Fig. 3 Comparison of brake specific fuel consumption

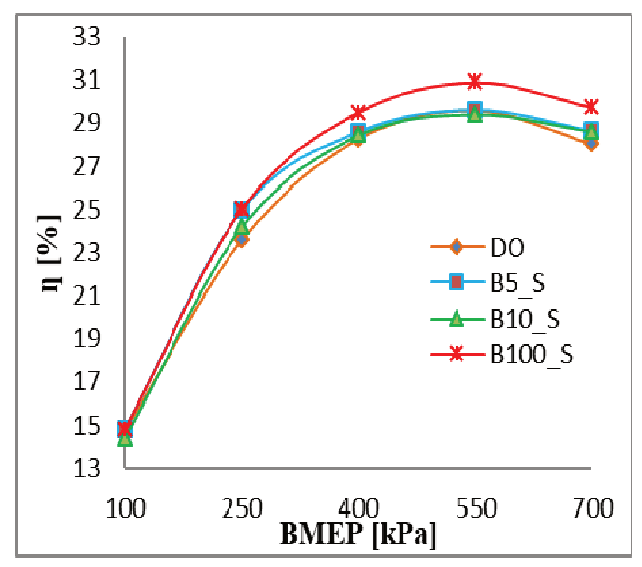

Fig. 4 Comparison of brake thermal efficiency

\subsection{Engine Emissions}

The change in $\mathrm{NO}_{\mathrm{x}}$ emission and smoke density of examined fuel samples is shown in Figs 5 and 6 for the engine speed $1600 \mathrm{rev} / \mathrm{min}$. It shows that the $\mathrm{NO}_{\mathrm{x}}$ emissions of the biodiesel fuels increase when the higher fraction of biodiesel fuel was applied. The values of $\mathrm{NO}_{\mathrm{x}}$ emission increase from $100 \mathrm{kPa}$ to $550 \mathrm{kPa}$ and reach the maximum value at the load of $550 \mathrm{kPa}$, then decrease at the load of $700 \mathrm{kPa}$. In contrast to the increase in $\mathrm{NO}_{\mathrm{x}}$, there is a reduction of smoke density. The oxygen content in biodiesel fuel and the mixture of biodiesel and diesel helps the oxidization better, thus cutting an amount of smoke density emitted from the engine. However, the improved 
combustion means that the temperature of the combustion process is higher which makes the amount of emitted $\mathrm{NO}_{\mathrm{x}}$ increase.

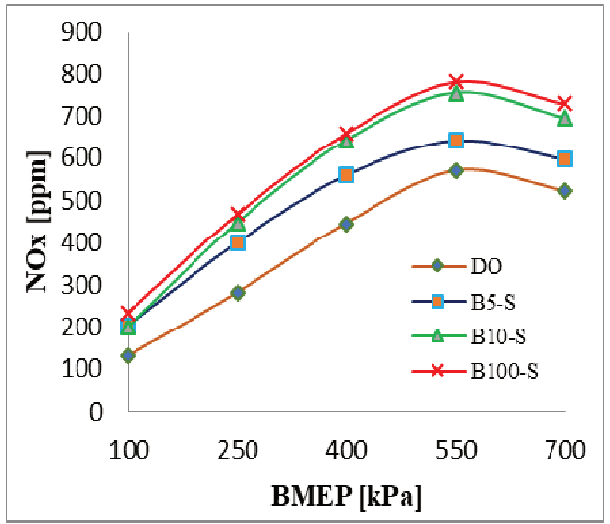

Fig. 5 Comparison of NOx emission

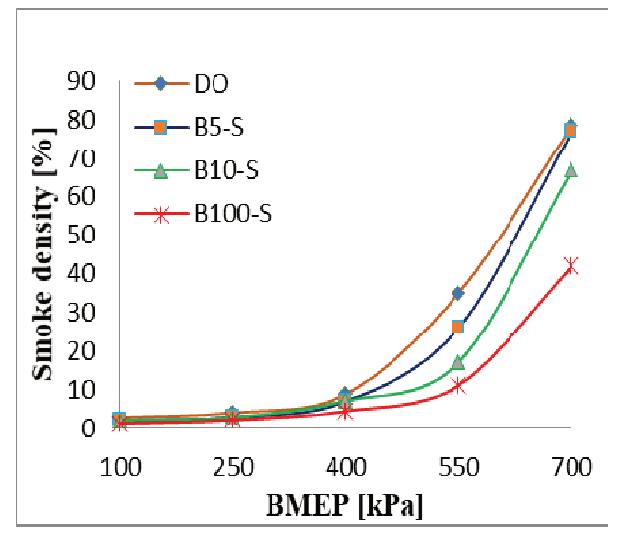

Fig. 6 Comparison of smoke density

\subsection{Combustion characteristics}

Fig. 7 shows the pressure curves for examined fuel samples at the load of $700 \mathrm{kPa}$. From the results of the pressure curve we can see that the peak of all curves is at the same position 10 degrees of crank angle after the top dead centre. The pressure curve of the B100S fuel is the highest and the diesel is the lowest. The oxygen content of the biodiesel fuel blends increases gradually with the mixing ratio, which makes the combustion temperature higher than the diesel fuel, causes higher cylinder pressure and also causes higher $\mathrm{NO}_{\mathrm{x}}$ levels than the diesel fuel. Although biodiesel blends have a lower cetane index than diesel fuel, the ignition delay of B100S fuel is the shortest and of diesel fuel is the longest. On the other hand, the density of mixing fuels is higher than diesel fuel, which means higher amount of fuel is entering into the combustion chamber for the same volume. We can say that the increase in $\mathrm{NO}_{\mathrm{x}}$ formation is caused by the fact that a higher amount of fuel means that more oxygen content is entering into the chamber.

Fig. 8 illustrates the rate of heat release (ROHR) of biodiesel compare to conventional diesel fuel. The result indicated that the starting point of the combustion process and the percentage of biodiesel fuel in the mixture increases, the ignition delay of $\mathrm{B} 100 \mathrm{~S}$ is the shortest and the starting point of the combustion process is earlier. The peak of the heat curve of the B100S is the highest and the earliest available rate is about 6 degrees of crank angle before the top dead centre and then B10S and finally the B5S and diesel. This can be explained by the slightly higher viscosity and cetane number of biodiesel. Another reason may be that a complex and rapid pre-flame chemical reaction takes place at high temperatures, as a result of the high in-cylinder gas temperature of existing fuel injection, biodiesel may undergo thermal cracking and lighter compounds are produced, which causes an earlier ignition and therefore a shorter ignition delay. With the higher temperature of blending biodiesel fuel in cylinder, this can also be true for the higher $\mathrm{NO}_{\mathrm{x}}$ emission component of biodieseldiesel fuel. 


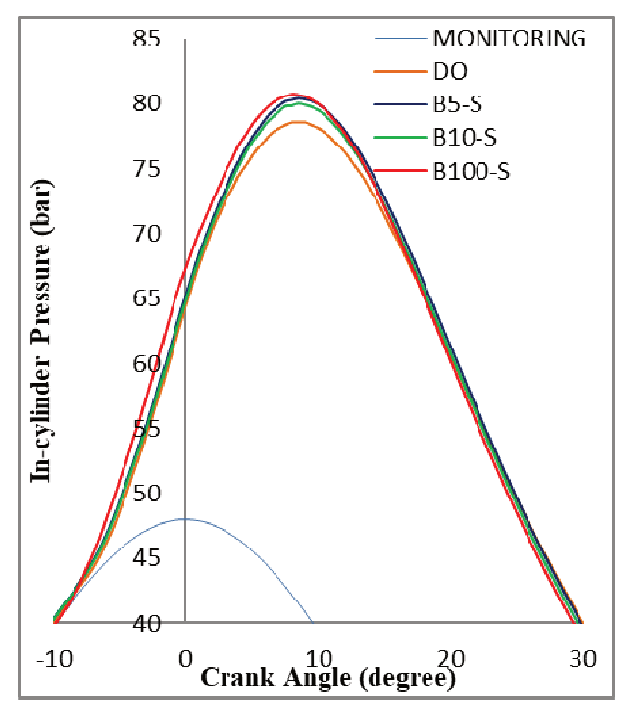

Fig. 7 Comparison of combustion

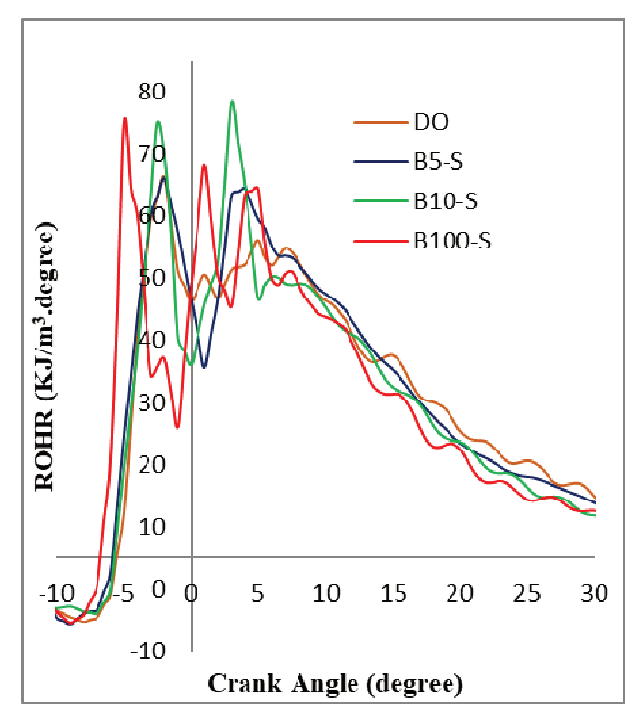

Fig. 8 Comparison of rate of heat release

\section{Conclusion}

The paper presents results of experimental research for assessment of net biodiesel, comparing blending biodiesel fuels produced by supercritical methods using rubber seeds oil with the diesel engine without any modification. The following conclusions were reached after performing the experiments:

- the brake specific fuel consumption of biodiesel fuel is larger than diesel fuel at the same speed and load due to the lower high heating value and higher density of biodiesel fuel comparing to diesel fuel. The higher fuel consumption of biodiesel compared with diesel fuel leads to higher brake thermal efficiency. The use of biodiesel will lead to loss in energy power mainly due to the reduction in heating value of biodiesel compared to diesel,

- the experiment tests shows that $\mathrm{NO}_{\mathrm{x}}$ content increases when the percentage of biodiesel in the mixture fuel is raised and on the contrary the smoke density of biodiesel decreases. The increase of $\mathrm{NO}_{\mathrm{x}}$ is caused by the higher amount of biodiesel, which leads to a higher temperature of combustion process. Another reason is that the density of biodiesel is higher than that of diesel, which explains why the amount of biodiesel fuel entering into combustion is also chamber higher,

- the cetane number of biodiesel and the slightly higher viscosity are properties that influence on the ignition delay. The ignition delay of biodiesel and the blend fuel including a portion of biodiesel are shorter than diesel fuel. The short ignition and the advanced injection timing for biodiesel ensure improved combustion of the fuel during the main combustion phase,

- we can conclude that small amount of the blends of biodiesel could replace diesel to help control air pollution and ease the pressure on scarce resources to a great extent without significantly reducing engine power and economy, 
- the results obtained from the experimental research of biofuels show that they can be used for military vehicles without the need for engine adjustment if the amount of biodiesel is less than $10 \%$. In the case of using a $100 \%$ percentage biofuel, the adjustment of the early injection timing should be adjusted to ensure that the top of the pressure curve is after the top dead centre.

\section{Acknowledgement}

This work has been supported by the Internal Combustion Engine laboratory, Ho Chi Minh City University of Technology and has been supported by the institutional funding University of Defence in Brno DZRO K-202 "MOBAUT".

\section{References}

[1] PANDEY, A., CHANG, J.S., HALLENBECK, P.C. and LARROCHE, C. Biohydrogen. San Diego: Elsevier, 2013. 588 p. ISBN 978-0-444-59555-3.

[2] PANDEY, A. Handbook of Plant-based Biofuels. Boca Raton: CRC Press, 2008. 314 p. ISBN 978-1-56-022175-3.

[3] HAI, N.G., ANH, P.T., CONG, H.T., PHUNG, L.T.K., VIET, T.T., HAI, V.N. and AZETSU, A. Prediction of Density and Kinematic Viscosity of Biodiesel Fuels Produced from Rubber Seed Oil. International Journal of Renewable Energy and Environmental Engineering, 2015, vol. 3, no. 4. ISSN 2348-0157.

[4] RAMADHAS, A.S., MURALEEDHARAN, C. and JAYARAJ, S. Performance and Emission Evaluation of a Diesel Engine Fueled with Methyl Esters of Rubber Seed Oil. Renewable Energy, 2005, vol. 30, no. 12, p. 1789-1800. DOI 10.1016/ j.renene.2005.01.009.

[5] RAMADHAS, A.S., JAYARAJ, S. and MURALEEDHARAN, C. Biodiesel Production from High FFA Rubber Seed Oil. Fuel, 2005, vol. 84, no. 4, p. 335-340. DOI 10.1016/j.fuel.2004.09.016.

[6] JOSE, D.F.M., RAJ, R.E., PRASAD, B.D., KENNEDY, Z.R. and IBRAHIM, A.M. A Multi-Variant Approach to Optimize Process Parameters for Biodiesel Extraction From Rubber Seed Oil. Applied Energy, 2011, vol. 88, no. 6, p. 20562063. DOI 10.1016/j.apenergy.2010.12.024.

[7] MORSHED, M., FERDOUS, K., KHAN, M.R., MAZUMDER, M.S.I., ISLAM, M.A. and UDDIN, M.T. Rubber Seed Oil as a Potential Source for Biodiesel Production in Bangladesh. Fuel, 2011, vol. 90, no. 10, p. 2981-2986. DOI 10.1016/j.fuel.2011.05.020.

[8] SHOKIB, A., GUMANTI, P. and RACHIMOELLAH, M.R. Biodiesel Production from Rubber Seed Oil by Supercritical Methanol Method. Journal for Technology and Science, 2010, vol. 21, no. 2. DOI 10.12962/j20882033.v21i2.32.

[9] SAWANGKEAW, R., BUNYAKIAT, K. and NGAMPRASERTSITH, S. A Review of Laboratory-Scale Research on Lipid Conversion to Biodiesel with Supercritical Methanol (2001-2009). Journal of Supercritical Fluids, 2010, vol. 55, no. 1, p. 1-13. DOI 10.1016/j.supflu.2010.06.008. 